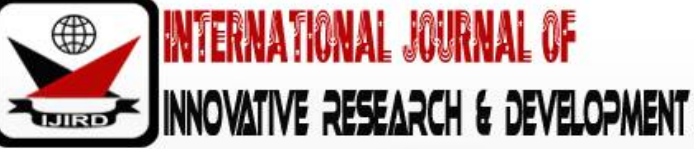

ISSN 2278 - 0211 (Online)

\section{Livelihood Vulnerability Approach to Assessing Climate Impacts on Smallholders in Kisumu, Kenya}

\author{
Thomas 0. Opande \\ Student, Institute for Climate change and Adaptation, University of Nairobi, Kenya \\ Daniel 0. Olago \\ Professor, Institute for Climate change and Adaptation, University of Nairobi, Kenya \\ Simeon 0. Dulo \\ Lecturer, Institute for Climate change and Adaptation, University of Nairobi, Kenya
}

\begin{abstract}
:
Climate change vulnerability depends upon various factors and differs between places, sectors and communities. Subsistence farmers in Africa including Kenya have been identified as particularly vulnerable. However, the knowledge on causal effects and dynamics surrounding their vulnerability is still limited.

This study aims to test vulnerability assessment indices, livelihood vulnerability index and IPCC vulnerability index, around Katuk Odeyo, in Kisumu Kenya. A total of 315 small householders were surveyed. Data on socio demographics, livelihood determinants, social networks, health, food and water security, natural disasters and climate variability was collected and combined into indices for respective sub-components and three dimensions (exposure, sensitivity and adaptive capacity) of vulnerability.

The findings help in designing site-specific intervention strategies to reduce vulnerability of subsistence smallholders to climate change.
\end{abstract}

Keywords: Vulnerability, climate change, subsistence farmers

\section{Introduction}

According to Adger et al. (2004) \& Kasperson and Kasperson (2000), Climate change has become a global problem irrespective of regions, countries, sectors and communities with differed impression. Skoufias et al. (2011) and IPCC (2007), highlighted that developing countries like Kenya, due to its disturbed economic condition and few accesses to alternative way of production has to suffered most. Among other climate related issues Climate change especially irregularity in temperature and rainfall is main problem area for Kenya (MoALF, 2014). Moreover, the sustainability of sensitive natural resource dependent sectors such as water, biodiversity, and agriculture are undermined by the predominant rain-fed agricultural practices (FAO, 2017). Further, droughts and unpredictable rainfall are now the norm in various parts of the country (MoALF, 2017). Particularly arid and semi-arid areas are being most impacted, in terms of crop production, livestock rearing (Hillel and Rosenzweig, 1989; GoK, 2013), fish cultivation, availability of water, diseases and insects (Thornton et al., 2009).

Some estimates place the costs to the Kenyan economy directly associated to droughts and flooding at around $2.4 \%$ of the per annum Gross Domestic Product (GoK, 2013).

Despite the fact that farming in Kenya is mostly subsistence in nature, to date limited information exists on how various complexities and interplays surrounding climate risks and socioeconomic factors undermine community wellbeing especially with regards to climate adaptation. This study therefore, aims to fill this gap by constructing and interpreting vulnerability indices for smallholder farmers in Katuk Odeyo, Kisumu County.

Climate change vulnerability is dynamic and dependent upon biophysical and social processes (IPCC, 2014; O'Brien et al., 2005). Initial assessment of contributing factors to climate vulnerability precedes the design of adaptation strategies (Ford and Smit, 2004), and also informs policies and risk reduction programs (Fussel and Klein, 2006). Vulnerability is not easily reduceable to a single metric nor is it easily quantifiable (Alwang et al., 2001). Therefore, development of robust and credible measures for vulnerability research is challenging due to complexities associated with examining and integrating interactions between humans and their physical and social surroundings (Singh et al., 2018). No consensus has been reached on a single method for assessing vulnerability (Adger, 2006; Singh et al., 2018). Most of the experiments focus on risks, damages, and up to how much it can be recovered (Cutter, 2003; Eakin and Luers, 2006). This is the reason of practicing a realistic approach to check assailability of some components along with its ability of accommodative power (Panthi et al., 2015; Singh et al., 2018). A large number of experimenters preferred to check vulnerability with the means of examining exposure, sensitivity and adaptive capacity (Turner et al., 2003). An indicator- 
based procedure has been established by Hahn et al., (2009) to compare among several types of indices based on their respective indicators (Aryal et al., 2014; Etwire et al., 2013; Pandey and Shah et al., 2013).

In this study, livelihood vulnerability index (LVI) has been introduced as a composite index for most of the major parameters. Taking reference from the IPCC vulnerability approach important parameters are segregated into three domains: 1. exposure, 2. sensitivity and 3. adaptive capacity. Present research aims to calculate and compare among many indices for livelihood of farmers.

\section{Methods}

\subsection{Concept of Livelihood Vulnerability Index (LVI)}

LVI was actually made for development organizations, policy makers and planners, which aimed to assist them by providing some area-oriented solutions for climate vulnerability in terms of demographic, social and physical factors. Along with composite index many vulnerability indices made for different sectors can be utilized to find capable segments for intercession (Hahn et al., 2009). Chambers and Conway (1992) highlighted the fact that how five types of household assets: natural, social, financial, physical and human capital can be combined by Sustainable Livelihood Approach (SLA), where LVI contributes more features of dimensions to climate hazards.

Impacts of whether variability can be found in the study of Etwire et al. (2013), and Hahn et al. (2009) where both primary and secondary data had been obtained from households and several parameters like flooding, temperature and rainfall respectively. This research aimed to formulate LVI with analysis technique, suggested by Hahn et al., (2009) by alternating some parameters such that it could increase acceptability among local farmer context (Table 1). For example, lack of technical data to calculate frequency of 'natural disasters' and 'climate variability' participatory tools had been used along with eight very important parameters: socio-demographic profile, livelihood strategies, social networks, health, access to food, access to water, natural disaster risks and climate variability. To find out actual scenario Government extension workers and the local village elders were also conferred. Data about standard temperature on monthly basis as well as deviations in rainfall can be collected from the meteorology station in Sondu and the World Bank portal for development practitioners' and policy makers. As per Panthi et. al. (2015), variability in climate without increase up to the level of "natural disaster" still it can hamper the income and rural livelihood along with less possibility to avoid risks.

\subsection{Calculation}

Table 1 represents eight important LVI components along with sub-components or indicators, functionality. Here reference for constructing LVI taken from Hahn et al., (2009) for its suitableness in the area of resource-poor settings (Aryal et al., 2014; Singh et al., 2018). As sub-components are being measure in different scales, more over this proposed framework gives equal weightage for each sub-component, standardization has to be done. For standardizing numerical values constructing equation of the Human Development Index-HDI is as follows (UNDP, 2007):

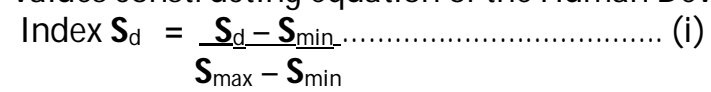

$\mathbf{S}_{\mathrm{d}}$ indicates the original sub-component, whereas minimum and maximum values denoting low and high vulnerability for each sub-component is being represented by $\mathbf{S}_{\min }$ and $\mathbf{S}_{\max }$. For instance, sub-component ranged from 0 to 12 to show the 'average number of months households struggle for food'. To get a standardized value between 0 and 1 minimum and maximum values were used. In case of measuring frequencies, 0 is the minimum value whereas $100 \%$ is the maximum one. As it is assumed that increase in the number of crop species planted by households decreases vulnerability by spreading risks, some sub-components such as 'average crop diversity index' were constructed as the inverse of the crude indicator.

Maximum and minimum values were transformed by this expression for crop diversity index is [1/ (number of crop species +1$)$ ]. To standardize this sub-component below mentioned equation (2) has been applied. By averaging standardized sub-components, an index for each major component was thereafter created.

$$
\mathrm{M}=\frac{\sum_{\mathrm{i}=\perp 1}^{\mathrm{n}}}{\mathrm{n}} \text { index } \mathrm{S}_{\mathrm{i}}
$$

Where, $\mathbf{M}$ is one of the eight major components, $\mathbf{S}$ is a sub-component, indexed by $\mathbf{i}$, that make up the major component, and $\mathbf{n}$ is the number of sub-components in each major component. After calculating each of the eight major vulnerability components, they were averaged using Eq. (3) to obtain the LVI:

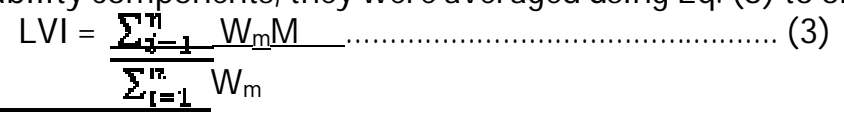

Where, $\mathrm{W}_{\mathbf{m}}$ is the weight of each major component calculated by placing equal contribution for all sub-components and LVI is the weighted average of the eight major components ( Sullivan et al., 2002; Singh et al., 2018). The LVI ranged from 0 (least vulnerable) to 1.0 (most vulnerable). 


\begin{tabular}{|c|c|c|}
\hline $\begin{array}{c}\text { Major } \\
\text { components }\end{array}$ & Sub-components & Assumed functional relationship \\
\hline \multirow{3}{*}{$\begin{array}{l}\text { Socio- } \\
\text { demographic } \\
\text { profile }\end{array}$} & $\begin{array}{c}\text { Dependency ratio: Ratio of independent } \mathrm{HH} \\
\text { members }(18-64 \text { years) to dependent } \mathrm{HH} \\
\text { members }(<18 \text { years and }>65 \text { years })\end{array}$ & A higher percentage reflects less adapting capacity \\
\hline & Percentage single headed $\mathrm{HH}$ & $\begin{array}{l}\text { Single headed households have less adapting } \\
\text { capacity (Mainly and Tan 2012) }\end{array}$ \\
\hline & $\begin{array}{l}\text { Percentage } \mathrm{HH} \text { who have not gone beyond } \\
\text { primary education }\end{array}$ & $\begin{array}{l}\text { Education makes people aware increasing their } \\
\text { coping ability to environmental changes }\end{array}$ \\
\hline \multirow{2}{*}{$\begin{array}{l}\text { Livelihood } \\
\text { strategies }\end{array}$} & $\begin{array}{l}\text { Percentage } \mathrm{HH} \text { without a family member } \\
\text { working outside the community }\end{array}$ & Income diversification increases adapting capacity \\
\hline & $\begin{array}{l}\text { Average agricultural livelihood } \\
\text { diversification index }\end{array}$ & $\begin{array}{c}\text { Diverse agricultural farming reduces risks and } \\
\text { losses }\end{array}$ \\
\hline \multirow[t]{3}{*}{ Social network } & $\begin{array}{c}\text { Percentage HH not getting any support from } \\
\text { government }\end{array}$ & $\begin{array}{l}\text { Adaptive capacity can be strengthened by support } \\
\text { from Government. }\end{array}$ \\
\hline & $\begin{array}{c}\text { Ratio between Average borrow and Lend } \\
\text { money }\end{array}$ & $\begin{array}{l}\text { Financial stress as well as less adaptive capacity } \\
\text { can be outcome of high borrowing. }\end{array}$ \\
\hline & Ratio between Average receive: Give money & $\begin{array}{l}\text { Without receiving results high amounts given in } \\
\text { financial stress and less adaptive capacity }\end{array}$ \\
\hline \multirow{3}{*}{ Health } & Average time to health facility & The shorter the less vulnerability it is \\
\hline & $\begin{array}{l}\text { Due to sickness percentage HH with a family } \\
\text { missing work/ school in the last } 2 \text { weeks }\end{array}$ & $\begin{array}{l}\text { This indicates how a family is being affected by } \\
\text { illness. A higher sensitivity associated with higher } \\
\text { percentage }\end{array}$ \\
\hline & $\begin{array}{l}\text { Percentage } \mathrm{HH} \text { with family member suffering } \\
\text { from long term illness }\end{array}$ & $\begin{array}{l}\text { Family with illness members are found to be more } \\
\text { sensitive }\end{array}$ \\
\hline \multirow{4}{*}{ Food } & $\begin{array}{l}\text { Percentage HH depending solely on family } \\
\text { farm for food }\end{array}$ & Higher sensitivity due to limited food sources \\
\hline & $\begin{array}{l}\text { Percentage } \mathrm{HH} \text { with enough food for the } \\
\text { whole year }\end{array}$ & Enough food implies less sensitivity \\
\hline & Percentage HH saving seeds & Lower level implies higher sensitivity to disasters \\
\hline & $\begin{array}{l}\text { Average no. of months a HH struggles to get } \\
\text { food }\end{array}$ & More months implies high sensitivity \\
\hline \multirow[t]{3}{*}{ Water } & $\begin{array}{l}\text { Percentage HH reporting water conflicts in } \\
\text { the previous years }\end{array}$ & $\begin{array}{l}\text { This tries to find out how the community is } \\
\text { affected by water scarcity. A higher sensitivity is } \\
\text { being indicated by a higher percentage }\end{array}$ \\
\hline & Average time to the water source nearby & A shorter time indicates less sensitivity \\
\hline & $\begin{array}{l}\text { Percentage HH having consistent water } \\
\text { supply }\end{array}$ & $\begin{array}{c}\text { A supply, consistent in nature implies less } \\
\text { sensitivity }\end{array}$ \\
\hline \multirow{3}{*}{ Natural disasters } & $\begin{array}{c}\text { Average frequencies of flood events in the } \\
\text { past } 10 \text { years }\end{array}$ & More reflects high exposure \\
\hline & $\begin{array}{c}\text { Average frequencies of landslide events in } \\
\text { the past } 10 \text { years }\end{array}$ & More reflects high exposure \\
\hline & $\begin{array}{c}\text { Average frequencies of drought events in the } \\
\text { past } 10 \text { years }\end{array}$ & More reflects high exposure \\
\hline \multirow{5}{*}{$\begin{array}{l}\text { Climate } \\
\text { variability }\end{array}$} & $\begin{array}{l}\text { Average number of consecutive ( } 3 \text { days) dry } \\
\text { spells for the last } 10 \text { yrs }\end{array}$ & More reflects high exposure \\
\hline & $\begin{array}{l}\text { Average number of consecutive ( } 3 \text { days) } \\
\text { warm days for the last } 10 \text { yrs }\end{array}$ & More reflects high exposure \\
\hline & $\begin{array}{l}\text { Percentage HH who have experienced daily } \\
\text { temperature changes }\end{array}$ & More reflects high exposure \\
\hline & $\begin{array}{l}\text { Percentage } \mathrm{HH} \text { who have experienced annual } \\
\text { temperature changes }\end{array}$ & More reflects high exposure \\
\hline & $\begin{array}{l}\text { Percentage HH who have experienced } \\
\text { climate impacts in food production }\end{array}$ & More reflects high exposure \\
\hline
\end{tabular}

Table 1: Major Components and Sub-Components, Information Sources Along with Their Functional Relationship with Vulnerability

\subsection{Calculating Livelihood Vulnerability: IPCC Framework Approach}

By highlighting the exposure, adaptive capacity and sensitivity levels (Hahn et al., 2009), natural disasters and climate variability were framed under 'exposure'. Similarly, water, food and health sectors were framed under 'sensitivity'; while socio-demographic profiles, livelihood strategies and social networks framed under 'adaptive capacity'. This enabled 
exposure to be quantified through determination of the frequency of natural disasters and climate variability in the last 20 years, adaptive capacity quantified by analyzing the demographic profiles (e.g., percentage of female headed households), types of livelihood strategies (e.g., percentage of household working outside), strength of social networks (e.g., borrow/ lend ratio), and sensitivity quantified by examing the food security situation, water accessibility and health status at the household level.

VI IPCC = exposure + adaptive capacity + sensitivity

\subsection{The Study Area}

The semi-arid study area is located within a $10 \mathrm{~km}$ by $10 \mathrm{~km}$ block on the plains of Lake Victoria. (Refer to map in Figure 1). The area also known as Katuk Odeyo is experiencing food insecurity, complex socio economic, environmental challenges (Raburu et al., 2012; Odada et al., 2004) and low farm labour productivity (Förch et al., 2013). Further, cultivation areas have been fragmented due to population pressure (Recha et al., 2017). Thus, identification and implementation of appropriate site-specific adaptation options for this smallholder community, is underpinned by initial vulnerability assessment as a major step in the design process (Ford and Smit, 2004).

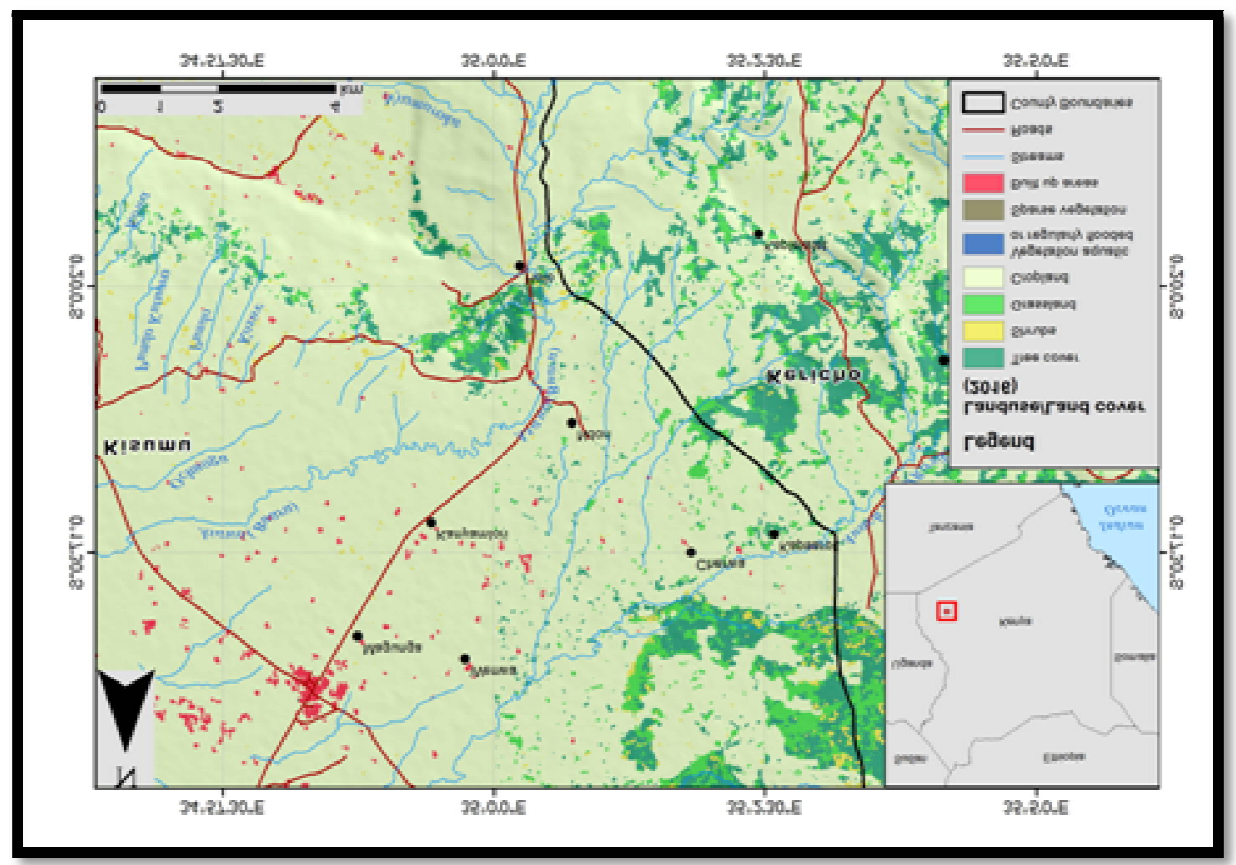

Figure 1: A Map of the Study Area

\subsection{Data Sources and Sampling Procedure}

A stratified random sampling approach (Abdul-Razak and Kruse, 2017) targeted 315 households (Lemma, 2016). Following acquisitions of the village 'population ' register, household heads or senior members were targeted. Internal quality control procedures enabled a common definition, where respondents interpreted survey questions differently. Various participatory tools (Singh et al., 2018 were adopted to obtain the respective vulnerability indicators. Records of drought and flooding were collected using key informant interviews and focused group discussions, temperature and rainfall data were collected from the meteorological station in Sondu and the World Bank knowledge portal for development practioneers and policy makers.

\section{Results}

\subsection{Livelihood Vulnerability Index (LVI)}

Overall results indicate a very high climate vulnerability (0.780) mainly due to inadequate social networks, livelihood strategies, availability of land and poor tenure systems, depleted natural resources, and poor water availability (Fig. 2) 


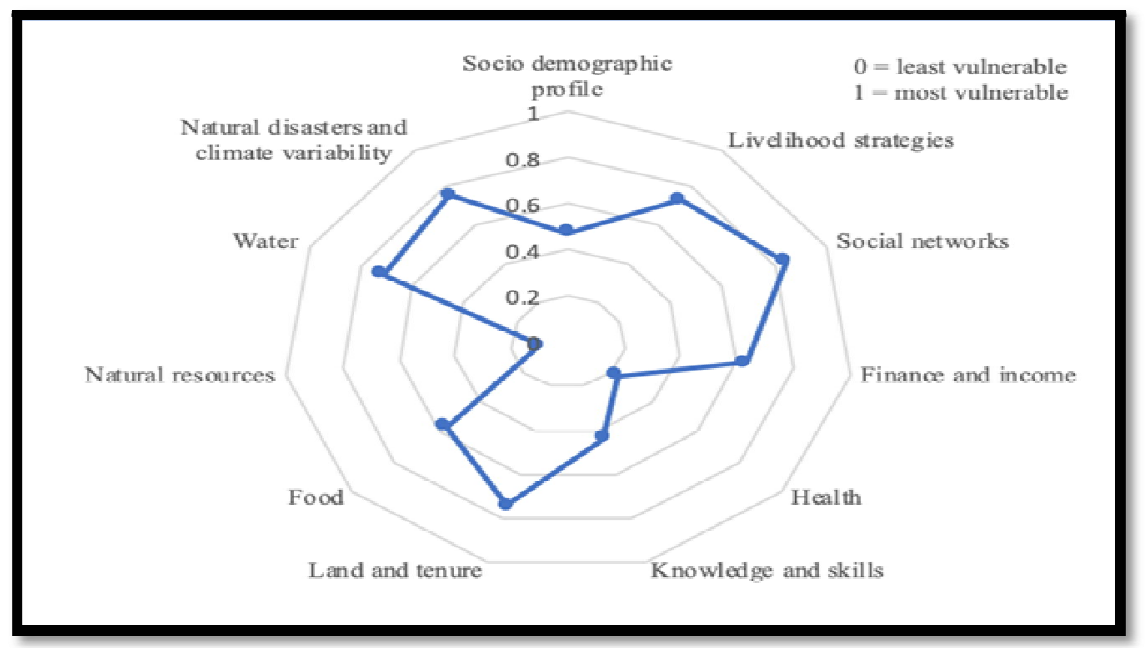

Figure 2: A Spider Diagram Showing Weight Of

Major Components Causing Vulnerability

\subsection{Assessing Vulnerability}

Vulnerability was determined by analyzing adaptive capacity, sensitivity and exposure (IPCC, 2014). By categorizing adaptive capacity as income (finance and income, livelihood strategies), infrastructure (water and health), education (skills and knowledge), and agricultural facilities (land/ tenure and food) (Lal, 2014), a weight of 0.645 indicates a low adaptive capacity. Similarly, by categorizing community sensitivity as components from physical damage, environmental (natural resources, and natural disasters) and social (social networks and demographic profiles), a weight of 0.701 is moderately high. Further, exposure to climate extremes due to rainfall and temperature variations was very high standing at 0.993

\begin{tabular}{|c|c|}
\hline Contributing Factors & LVI Weight \\
\hline Adaptive capacity & 0.645 \\
\hline Sensitivity & 0.701 \\
\hline Exposure & 0.993 \\
\hline Overall LVI & 0.780 \\
\hline
\end{tabular}

Table 2 Table Showing the Overall LVI

\section{Discussions}

\subsection{Vulnerability Assessment}

Overall results from the subcomponents indicate that vulnerability is caused by food insecurity, exposure to temperature variability, frequent flood incidences, poor access to portable water, ecosystem benefits, poor and climate smart housing, over dependence on agriculture as the main livelihood source, averagely high borrowing rates, and inadequate extension services and/ or government support. Further, with several natural water sources drying up (GOK, 2014; Recha, 2017), 51.7\% of respondents are forced to walk for more than an hour to reach the nearest water source. A further,78.7\% have experienced water conflicts in the past 12 months. Despite water related challenges, very few farmers practiced drip irrigation or climate smart agriculture due to inadequate extension services and financial support among other reasons. Water vulnerability of rural households is particularly common when farmers rely on rainfed agriculture (Pandey et al., 2014). Additional findings indicate that the community rely on social networks such as farmer-based groups and faith-based organisations (including churches) for food assistance in times of crisis, micro-credit facilities, and support with natural resource management initiatives. It was also discovered that huge gulley's formed as a result of erosion over many years, had divided homes and families and therefore limited social interactions between homesteads. It was however, revealed that the existing social networks enabled sharing of vital information such as impending droughts and opportunities related to temporary migration for off farm employment during environmental hazards.

Additionally, a high dependency rate, exacerbated by a high proportion of single headed households has created challenges with caring and feeding both the young and elderly. This has further undermined the adaptive capacity by bringing into play a gamut of complexities associated with unavailability of healthy farm hands, more mouths to be fed, and extra expenditure on medicine, and school fees. Several writers have documented the importance of social capital in coping with adverse environmental and climate change impacts (Adger, 2006; Osbahr et al., 2010). For instance, Sallu et al., (2010) observed that socially connected households in Botswana were able to effectively take advantage of institutional and economic support for reducing vulnerability associated with climate change and variability.

Recently, changes in agricultural practices such as reduced crop rotation, mono-cropping, and absence of complementary practices to no-tillage systems have been associated with increased impacts of flood events (Eakin et al., 2006). Locally, floods have inflicted a high social cost; causing losses in harvests, damage to properties, land degradation and a huge gulley. Community response strategies to floods are weak due to inadequate early warning systems and smaller landholdings which have a higher probability of flood induced property damage. Low education level of household heads and inadequate income diversification options were further identified as key contributing factors to the higher LVI 
since $58.9 \%$ of respondents did not complete primary level of education. Good education can potentially enhance adaptive capacity (O'Brien et al., 2004), by increasing awareness, coping mechanisms (Antwi-Agyei, 2012) adoption potential of new agricultural technologies (Techoro, 2013), and uptake of climate information (Paavola, 2008).

On the other hand, climate data show changing patterns since 1990, which has compelled the farmers to change their planting seasons. Most respondents were of the view that the rainy season was characterised by high intra-annual variability and torrential rainfall, which may not be that useful for rain-fed agriculture. In general, the respondents had a common consensus that rainfall trends had changed over the years indicating a decrease in precipitation quantity and delay in seasonal onsets. This variability in climate, has negatively impacted food production systems of $96.3 \%$ respondents especially since the farmers are unable to precisely predict the seasonal onset due to inadequate climate information (Recha et al., 2017).

Overall findings indicate a very high LVI of 0.780 (Fig. 3). These results compliment findings by Gbetibouo et al. (2010) that vulnerability of subsistence farmers to drought is linked to socioeconomic characteristics and degree of capital development; and Sen (1981) and Moser (1998) that entitlement of individuals to five capital assets (financial, human, natural, physical, and social) enhances adaptive capacity to climate change and variability. For instance, human capital assets such as education can enhance adaptive capacity (Brooks et al., 2005) by increasing opportunities for rural households to earn supplementary income (Moser, 1998). These results have thus confirmed that overall precipitation is declining, climate information to predict seasonal onset and climate patterns is inadequate and community adaptive capacity has been undermined by a gamut of complexities and dynamics surrounding several socioeconomic factors.

\subsection{Implications to Farmer Wellbeing and Recommendations}

The study highlights several site-specific causal effects to different vulnerability components that have undermined the well-being of the farmers. Instrumentalism was found in case of framing actions to improve adaptive capacity by reducing vulnerability. Ghimire et al. (2010), highlighted the necessity of livelihood to lessen vulnerability. Integration of crops and livestock by smallholders enhances diversification and spreading of systematic climate threats (Lal, 2014). Improving infrastructure can reduce vulnerability especially by expanding rural water and electrification systems, constructing access roads and community markets. Rainwater harvesting, and water storage systems are potential alternative options for reducing water problems. Similarly, drip irrigation systems, climate smart agriculture, ecosystem-based adaptation (EbA) and Sustainable Land Agroecological Management techniques (SLaM) (FAO, 2017) can act as effective options for enhancing agricultural productivity, underground water recharge, reducing the escalating land degradation and biodiversity losses. Further, periodic agriculture and veterinary camps can act as cost-effective approaches and entry points for penetration by government extension services. Planting nutritional fodder trees and forage species as community-based adaptation strategies will diversify livestock nutrition requirements, and control soil erosion, and land degradation (Aryal et al., 2014). According to Heltberg et al. (2009), livelihood diversification and risk management efforts can be well managed by introducing various microfinance packages. Although it is under development but livestock and agriculture insurance are beneficial options to mitigate climate related losses. Some other ways to fight against vulnerability are Farmer cooperative movements and other formal and informal community-based groups such as religious, common interest and women groups as all of these strengthen social networks. According to Castle (2002), links, shared values, understanding and trust among community members can be treated as an important social capital. These can be a strategy on which it can be relied upon for making response strategies strong during emergency situation. Pelling and High (2005), mentioned social ties and everyday social interaction as community assets, which as per Thomas et al., (2005) can be useful for improving bonds among many households.

\section{Limitations}

As mentioned earlier vulnerability measurement caters to various socio-political factors. As per Panthi et al. (2015), for many sectors and geographical areas especially in poor and resource constraint setups customized indicatorbased approaches mentioned in this study can be very effective. Still the main challenges lie for selecting suitable indicators and assigning appropriate weight. The main limitations of the indicator in this study are the level of subjectivity in indicator selection, and framing in the local context. Good result has been obtained from literature review and stakeholder engagement. Different households with unequal vulnerability have caused differed LVI. LVI indicator varies between studies. Numerical values only used while making comparison in the level of vulnerability such as between clans in this study. LVI of different studies can't be compared as contexts are entirely different along with relativity of indicators.

\section{Conclusions}

Impact caused by climate change can be measured by two related methods: LVI and VI-IPCC for assessments of aggregate and relative vulnerability of communities with detailed representation of relevant associated factors. Potential design of site-specific coping and community-based adaptation strategies by elaborating on causal chains, complexities and dynamics of vulnerability can be obtained by index values of each component and sub-component. Community development workers and development partners can therefore adopt the findings of this research in planning, and implementation of various climate adaptation interventions at both national and local levels This study has therefore identified various causal effects that undermine effective community response to climate risks. Gaps found in many experiments can be eliminated by adopting steps like: enhancing livelihood diversification, fostering asset building and infrastructure development, improvement of socio-economic factors such as education and awareness, adoption of improved livestock husbandry, mixed farming, organic farming, agroforestry, restocking farm animals to supplement 
human labour, incorporating micro credit schemes, and activities targeting land degradation, water availability, climate smart housing, and markets for development (M4D) etc.

As a whole, this study has increased the scope in context of rural Kenya by extending LVI developed by Hahn et al., (2009) and IPCC vulnerability (VI-IPCC) index. VI-IPCC framework is able to compare the level of contribution for exposure, sensitivity and adaptive capacity in case of overall vulnerability. Whereas, LVI distinguishes and can compare various sectors and aspects of vulnerability in the small-scale Kenyan farmer context. Targeted interventions and capacity building can therefore be adopted to enhance coping mechanisms associated with climate variabilities, impacts and sensitivities. It is important to note that both approaches can complement monitoring and evaluation of resilience enhancing interventions.

\section{References}

i. Abdul-Razak, M., Kruse, S. (2017) The adaptive capacity of smallholder farmers to climate change in the Northern Region of Ghana, Elsevier journal, climate risk management 17 (2017) $104-122$

ii. Adger, W. (2006) Vulnerability. Glob Environ Change 16:268-281. doi: 10.1016/j.gloenvcha.2006.02.006

iii. Adger, W Brooks, N Bentham, G Agnew, M Ereksen, S (2004) New indicators of vulnerability and adaptive capacity, Vol 7. Tyndall Centre for Climate Change Research, Norwich

iv. Alwang, J Siegel, P Jorgensen, S (2001) Vulnerability: a view from different disciplines. Discussion paper. Social Protection Unit, World Bank, Washington DC

v. Antwi-Agyei, P (2012) Vulnerability and adaptation of Ghana's food production systems and rural livelihoods to climate variability. PhD thesis, The University of Leeds, School of Eartha and Environment.

vi. Aryal, A Brunton, D Raubenheimer, D (2013) Impact of climate change on human-wildlife-ecosystem interactions in the Trans- Himalaya region of Nepal. Theoretical and Applied Climatology115:517-529. doi:10.1007/ s00704013-0902-4

vii. Aryal, S Cockfield, G Maraseni, T (2014) Vulnerability of Himalayan transhumant communities to climate change. Clim Change 125:193-208. doi:10.1007/ s10584-014-1157-5

viii. Brooks, N Adger, W Kelly, P (2005) The determinants of vulnerability and adaptive capacity at the national level and the implications for adaptation. Global Envi Change, 15(2):151-163.

ix. Castle, E (2002) Social capital: an interdisciplinary concept. Rural Social 67:331-349. doi:10.1111/j.1549-0831. 2002.tb00107.x

x. Chambers, R Conway, G (1992) Sustainable rural livelihoods: practical concepts for the 21st century. Institute of Development Studies (IDS), UK

xi. Climate Change, Agriculture and Food Security (CCAFS)/ Food and Agricultural Organization of the United Nations (FAO), (2014): Climate-Smart Agriculture: What is it? Why is it needed? Rome, Italy

xii. Cutter, S (2003) Vulnerability to environmental hazards. Soc Sci Q 84:242-261. doi:10.1111/ 1540-6237.8402002

xiii. Eakin, H Luers, A (2006) Assessing the vulnerability of social environmental systems. Annu Rev Environ Resour 31:365-394. doi: 10.1146/ annurev.energy.30.050504.144352

xiv. Eakin, H Webhe, M Avila, C Torres, G Bojorques-Tapia, L (2006) A comparison of the social vulnerability of grain farmers in Mexico and Argentina

xv. Etwire, P Al-Hassan, R Kuwornu, M, Osei-Owusu, Y (2013) Application of livelihood vulnerability index in assessing vulnerability to climate change and variability in Northern Ghana.J Environ Earth Sci 3:157-170

xvi. Food and Agricultural Organization of the United Nations, (2017) Sustainable Land Management (SLM) in practice in the Kagera Basin. Lessons learned for scaling up at landscape level - Results of the Kagera Transboundary Agroecosystem Management Project (Kagera TAMP). Food and Agriculture Organization of the United Nations, Rome, Italy. $440 \mathrm{pp}$.

xvii. Ford, J Smit, B (2004) A framework for assessing the vulnerability of communities in the Canadian Arctic to risks associated with climate change. Arctic 57:389-400. doi:10.14430/ arctic516

xviii. Fussel H-M, Klein R (2006) Climate change vulnerability assessments: an evolution of conceptual thinking. Clim Change 17:301-329. doi:10.1007/ s10584-006-0329-3

xix. Förch, W Sijmons, K Mutie, I Kiplimo, J Cramer, L Kristjanson, P Thornton, P Radeny, M Moussa, A Bhatta, G (2013). Core Sites in the CCAFS Regions: East Africa, West Africa and South Asia, Version 3. CGIAR Research Program on Climate Change, Agriculture and Food Security (CCAFS). Copenhagen, Denmark. Available online at: www.ccafs.cgiar.org

xx. Gbetibouo, G Ringler, C Hassan, R (2010) Vulnerability of the South African farming sector to climate change and variability: an indicator approach. Natural Resources Forum, 34(3): 175-187.

xxi. Ghimire, Y Shivakoti, P Perret, R (2010) Household-level vulnerability to drought in hill agriculture of Nepal: implications adaptation planning. Int J Sustain Dev World Ecol 17:225-230. doi:10.1080/ 13504501003737500

xxii. Ministry of Agriculture Livestock and Fisheries (MoALF), (2014) Government of Kenya (GoK) Agricultural Sector Development Support Programme (ASDSP), Nairobi, Kenya.

xxiii. Hahn, M Riederer, A Foster, S (2009) The Livelihood Vulnerability Index: a pragmatic approach to assessing risks from climate variability and change-a case study in Mozambique. Glob Environ Change 19:74-88. doi: 10.1016/j.gloenvcha.2008.11.002

xxiv. Haile, M (2005) Weather patterns, food security and humanitarian response in sub-Saharan Africa. Philosophical Transactions of the Royal Society, 360(1463): 2169. 
xxv. Hallegatte, S (2009) Strategies to adapt to an uncertain climate change. Glob Environ Change 19:240-247. doi: 10.1016/j.gloenvcha.2008.12.003

xxvi. Heltberg, R Siegel, P Jorgensen, S (2009) Addressing human vulnerability to climate change: toward a 'no-regrets' approach. Glob Environ Change 19:89-99. doi: 10.1016/ j.gloenvcha.2008.11.003

xxvii. Hillel, D Rosenzweig, C (2010) (eds). Handbook of Climate Change and Agroecosystems: Impacts, Adaptation, and Mitigation, London: Imperial College Press.

xxviii. IPCC (2001) Climate change 2001: impacts, adaptation, and vulnerability. In: McCarthy, J Canziani, O Leary, N Dokken, D White, K (eds) Contribution of Working Group II to the Third Assessment Report. Cambridge University Press, Cambridge, UK. http:/ / www.preventionweb.net/ files/ 8387 wg2TARfrontmatter1.pdf

xxix. IPCC (2007) Summary for policymakers. In: Parry ML, Canziani OF, Palutikof JP, van der Linden PJ, Hanson CE (eds) Climate change 2007: impacts, adaptation and vulnerability. Cambridge University Press, Cambridge. https:/ / www.ipcc.ch/ pdf/ assessment-report/ ar4/ wg2/ ar4-wg2-spm.pdf

xxx. IPCC (2014) Emergent risks and key vulnerabilities. In: Field CB, Barros VR, Dokken DJ, Mach KJ, Mastrandrea MD, Bilir TE, Chatterjee M, Ebi KL, Estrada YO, Genova RC, Girma B, Kissel ES, Levy AN, MacCracken S, Mastrandrea PR, White LL (eds) Climate change 2014: impacts, adaptation, and vulnerability. Part A: global and sectoral aspects. Contribution of Working Group II to the Fifth Assessment Report of the Intergovernmental Panel on Climate Change.

xxxi. Kasperson, R Kasperson, J (2001) Climate change, vulnerability and social justice. Risk and vulnerability programme. Stockholm Environment Institute, Stockholm

xxxii. Lal, S (2014) Climate Change Resilience and Vulnerability of Farmers in Nepal, PhD thesis, Graduate School for International Development and Cooperation, Hiroshima University, Japan

xxxiii. Lemma, W (2016) Analysis of Smallholder Farmers' Perceptions of Climate Change and Adaptation Strategies to Climate Change: The Case of Western Amhara Region, Ethiopia. PhD thesis, University of South Africa.

xxxiv. Lobell, D Burke, M (2008) Why are agricultural impacts of climate change so uncertain? The importance of temperature relative to precipitation. Environmental Research Letters, 3: p. 034007.

xxxv. Mainly, J Tan, F (2012) Mainstreaming gender and climate change in Nepal. IIED, London. http:/ / pubs.iied.org/ pdfs/ 10033IIED.pdf

xxxvi. Ministry of Agriculture, Livestock and Fisheries (MoALF) (2017) Climate Risk Profile for Kisumu County. Kenya County Climate Risk Profile Series - Nairobi, Kenya.

xxxvii. Moser, N (1998) The asset vulnerability framework: reassessing urban poverty reduction strategies. World Development, 26(1): 1-19.

xxxviii. O'Brien, K Leichenko, R Kelkar, UVenema, H Aandahl, G Tompkins, H Javed, A Bhadwal, SBarg, S Nygaard L (2004) Mapping vulnerability to multiple stressors: climate change and globalization in India. Global Environmental Change, 14(4): 303-313.

xxxix. O'Brien, K Eriksen, S Schjolden, A Nygaard, L (2005) What's in a word? Interpretations of vulnerability in climate change research. Oslo

xl. Odada, E Olago, D Kulindwa, K Ntiba, M Wandiga, S (2004) Mitigation of environmental problems in Lake Victoria, East Africa; Causal chain and policy options analyses. Ambio, (1-2): 13-23.

xli. Osbahr, H Twyman, C Adger, W Thomas, G (2010) Evaluating successful livelihood adaptation to climate variability and change in southern Africa. Ecology and Society, 15(2): 27.

xlii. Paavola, J (2008) Livelihoods, vulnerability and adaptation to climate change in Morogoro, Tanzania. Environmental Science \& Policy, 11(7): 642-654.

xliii. Pandey, R Kala, S Pandey, P (2014) Assessing climate change vulnerability of water at household level. Mitigation Adaptation Strategy Glob Change. doi:10.1007/ s11027-014-9556-5

xliv. Panthi, J Aryal, S Dahal, P Bhandari, P Krakauer, N Pandey, V (2015) Livelihood vulnerability approach to assessing climate change impacts on mixed agro-livestock smallholders around the Gandaki River Basin in Nepal. Reg Environ Change, Springer Doi:10.1007/ s10113-015-0833-y

xlv. Pelling, M High, C (2005) Understanding adaptation: What can social capital offer assessments of adaptive capacity? Glob Environ Change 15:308-319 doi: 10.1016/j.gloenvcha.2005.02.001

xlvi. Pradhanang, B Pradhanang, M Sthapit, A Krakauer, N Lakhankar, T Jha, K (2015) National livestock policy of Nepal: needs and opportunities. Agriculture 3:103-131. doi:10.3390/ agriculture 5010103

xlvii. Raburu, P Okeyo-Owuor, J Kwena, F (2012) Community based approaches to the management of Nyando wetlands, Lake Victoria Basin, Kenya. Nyando Wetland Utility Resource Optimization Project, Ref: - AKEN/ 05/ 427. KDC-VIRED-UNDP.

xlviii. Recha, T Gachene, C Claessens, (2017) Adapting Nyando smallholder farming systems to climate change and variability through modeling. African Journal of Agricultural Research Vol.12 (26) pp. 2178-2187

xlix. Sallu, M Twyman, C Stringer C (2010) Resilient or vulnerable livelihoods? Assessing livelihood dynamics and trajectories in rural Botswana. Ecology and Society, 15(4): 3.

l. Sen, A (1981) Poverty and famines: an essay on entitlement and deprivation. Oxford: Clarendon Press.

li. Shah, U Dulal, B Johnson, C Baptiste, A (2013) Understanding livelihood vulnerability to climate change: applying the livelihood vulnerability index in Trinidad and Tobago. Geoforum 47:125-137. doi: 10.1016/ j.geoforum.2013.04.004

lii. Skoufias, E Rabassa, M Olivieri, S Brahmbhatt, M (2011) The poverty impacts of climate change. Economic Premise, vol 5622. World Bank Policy Research Working Paper 
liii. Sullivan, A Meigh, R, Fediw, S (2002) Derivation and testing of the Water Poverty Index Phase 1 vol 1. Department for International Development (DFID), UK

liv. Techoro, S (2013) PhD thesis "Climatic Change Impacts on Subsistence Agriculture in the Sudano- Sahel Zone of Cameroon - Constraints and Opportunities for Adaptation". Faculty of Environmental Sciences and Process Engineering, Brandenburg University of Technology, Cottbus, Germany

lv. Thomas, D Osbahr, H Twyman, C Adger, W Hewiston, B (2005) ADAPTIVE: adaptations to climate change amongst natural resource-dependent societies in the developing world: across the Southern African climate gradient vol 35. Tyndall Centre for Climate Change Research Technical UK

lvi. Thornton, K Van de Steeg, J Notenbaert, A Herrero, M (2009) The impacts of climate change on livestock and livestock systems in developing countries: a review of what we know and what we need to know. Agric Syst 101:113-127. doi: 10.1016/ j.agsy.2009.05.002

lvii. Turner, BL et al (2003) A framework for vulnerability analysis in sustainability science. Proc Natl Acad Sci (PNAS) 100:8074-8079. doi:10.1073/ pnas.1231335100

lviii. UNDP. (2007) Human Development Report 2007/2008: fighting climate change: human solidarity in a divided world. New York: United Nations Development Programme. 